\title{
Physicochemical and antibacterial activities of Apis honey types derived from Coorg, Karnataka, India
}

\author{
Bhushanam M \\ Department of Zoology, Maharani Cluster University, Bangalore (Karnataka), India \\ Madhusudhan S \\ Department of Biotechnology, Maharani Cluster University, Bangalore (Karnataka), India \\ Monika Bajpai \\ Department of Chemistry, Indian Academy Degree College-Autonomous, Bangalore, \\ Karnataka, India \\ Sibi G* \\ Department of Biotechnology, Indian Academy Degree College-Autonomous, Bangalore \\ (Karnataka), India \\ *Corresponding author. Email: gsibii@gmail.com
}

\section{How to Cite}

Bhushanam M. et al. (2021). Physicochemical and antibacterial activities of Apis honey types derived from Coorg, Karnataka, India. Journal of Applied and Natural Science, 13(2), 729 - 734. https://doi.org/10.31018/jans.v13i2.2710

\begin{abstract}
Natural honey has various ingredients in it that contribute to its incredible properties. The aim of this investigation was to evaluate the physicochemical and antibacterial activity of various Apis honey from Coorg, Karnataka. Four samples of Apis honey viz., $A$. florea, $A$. mellifera, A. cerana and $A$. dorsata were collected from various regions of Coorg, Karnataka. The honey samples' physicochemical properties and antibacterial activities against Streptococcus sp., Staphylococcus aureus, Bacillus subtilis and Enterococcus sp were determined in vitro. The moisture and ash content varied from $13.6-17.2 \%$ and $0.32-0.49 \%$, respectively. Hydroxy methyl furfurals) content of $A$. dorsata honey samples was highest with $9.2 \pm 0.5 \mathrm{mg} / \mathrm{Kg}$ and least was recorded with $6.8 \pm 0.4 \mathrm{mg} / \mathrm{Kg}$ for $A$. florae honey. The reducing sugar content of $A$. florea honey sample was highest with $87.5 \pm 3.2$ (\%) and the peroxide levels were in the range of $10.2-14.9 \mu \mathrm{g} / \mathrm{g} / \mathrm{h}$ at $20^{\circ} \mathrm{C}$. The antibacterial assay revealed that $S$. aureus, Enterococcus sp and Streptococcus sp were most susceptible against the honey varieties tested and minimum inhibitory concentration (MIC) values between 25-6.5 (\%v/v) were determined. In conclusion, honey varieties from Coorg could be used in specific antibacterial prophylaxis as the activity depends on the honey bee species, their metabolism and floral sources in specific geographical regions.
\end{abstract}

Keywords: Apis honey, Coorg, Antibacterial, Peroxide, Physicochemical

\section{INTRODUCTION}

Honey is an easily digestible foodstuff containing a wide range of nutritiously important complementary elements. Besides the high content of a range of saccharides, there are also organic acids, amino acids, mineral matter, colouring-aromatic substances, and a trace of fats (Bogdanov et al., 1999). Honey also contains very valuable but unstable compounds, such as enzymes, substances of hormonal character, vitamins, and few minor compounds (Qui et al., 1999). The medicinal use of honey in wound treatment is derived from diverse ancient civilizations. A wide range of microbial species has shown to be inhibited by honey (Cooper et al., 2002). Antimicrobial use of honey has been reported since ancient times but modern dressings and antibiotic therapy superseded its use as an anti-infective agent. However, the emergence of bacterial pathogens and the potential of region specific honey variety have confounded the relook of honey and its antibacterial activity. Antibacterial resistance to honey is unlikely and has not been reported in the literature (Hussain, 2018) due to its synergistic antibacterial components (Sanz et al., 2005). In contrast to antibiotics, when consumed orally, beneficial gut flora is not disrupted by honey (Hussain et al., 2015) and also it enhances the growth of normal flora in the gastrointestinal tract (Mohan et al., 2017). Honey exhibits a unique, multifac- 
eted antibacterial activity against pathogenic bacteria as revealed by molecular and cellular studies (Blair et al., 2009; Kwakman et al., 2010). The antimicrobial properties of honey, along with activation of the immune system and healing process, are one of the main reasons for its medicinal use. Given the importance of a study that honeys might exert antimicrobial activity against pathogenic bacteria in a relationship with the honey bee varieties and floral sources, this investigation aimed to evaluate the physico-chemical and antimicrobial activity of various Apis honey from Coorg, Karnataka.

\section{MATERIALS AND METHODS}

\section{Study area}

Honey samples of $A$. florea, $A$. mellifera, $A$. cerana and A. dorsata were collected from Galibeedu region of Coorg, $\left(12.3375^{\circ} \mathrm{N}, 75.8069^{\circ} \mathrm{E}\right)$ Karnataka. Coorg is a diversified forest with multifloral region. The physicochemical properties of the honey samples were determined by following the standard methods.

\section{Determination of physicochemical parameters}

\section{pH}

The honey was diluted to $10 \%$ using distilled water and the $\mathrm{pH}$ was determined in a $\mathrm{pH}$ meter (Bogdanov et al., 2004).

\section{Moisture and ash content}

Moisture content in the honey was calculated by measuring the refractive index at $40^{\circ} \mathrm{C}$. Ash content of the honey was determined by heating the honey at $600^{\circ} \mathrm{C}$ in a muffle furnace for 2 hours followed by cooling (Bogdanov et al., 2004).

\section{Estimation of HMF (5-hydroxymethylfurfuraldehyde)} Five grams of honey were dissolved in $25 \mathrm{ml}$ of water, transferred quantitatively into a $50 \mathrm{ml}$ volumetric flask. To this, added $0.5 \mathrm{ml}$ of Carrez solution I and $0.5 \mathrm{ml}$ of Carrez II and the volume was made upto the mark with distilled water. The solution was filtered through paper, rejecting the first $10 \mathrm{ml}$ of the filtrate and $5 \mathrm{ml}$ of aliquots were put in two test tubes. To one tube was added 5 $\mathrm{ml}$ of distilled water (sample solution); to the second was added $5 \mathrm{ml}$ of sodium bisulphite solution $0.2 \%$ (reference solution). The absorbance of the solutions at 284 and $336 \mathrm{~nm}$ was determined using a UV-Vis spectrophotometer (White, 1979).

\section{Estimation of reducing sugars}

Reducing sugars present in the honey were estimated by dinitrosalicylic acid (DNS) method. A volume $(0.1 \mathrm{ml})$ of the honey sample previously dispersed in DMSO mixed with $0.4 \mathrm{ml}$ of distilled water was reacted on a boiling water bath for 8 minutes with $1 \mathrm{ml}$ of DNS rea- gent. After cooling in an ice bath for $3 \mathrm{~min}$, the absorbance was read at $546 \mathrm{~nm}$ on the spectrophotometer. The reducing sugar concentrations were calculated from the calibration curve using fructose as the standard.

\section{Determination of sucrose content}

Sucrose content of the honey was determined by the method described by White (1977). In brief, $1 \mathrm{~g}$ of honey was diluted in $15 \mathrm{ml}$ of water, boiled for 30 seconds, cooled and the volume was made up to $100 \mathrm{ml}$. From this solution, $5 \mathrm{ml}$ was taken and diluted to $50 \mathrm{ml}$, followed by $5 \mathrm{ml}$ of glucose oxidase-catalase reagent. The mixture was placed in $40^{\circ} \mathrm{C}$ water bath for 1 hour, cooled and $2 \mathrm{ml}$ was transferred to a fresh tube. To this, $2 \mathrm{ml}$ of invertase was added and the tube was held at room temperature for 30 minutes. The absorbance was read at $520 \mathrm{~nm}$ using glucose as standard.

\section{Peroxide content}

Screening for peroxide accumulation was carried out by dissolving $10 \mathrm{~g}$ of honey in $40 \mathrm{ml}$ of water. After 1 hour, peroxide test strip is dipped into the honey solution and the blue colour obtained is read after 15 seconds and compared with the colour scale. The obtained value, multiplied by five, gives the amount of hydrogen peroxide accumulation in micrograms per gram honey per hour at $20^{\circ} \mathrm{C}$ (Kerkvliet, 1996).

\section{Antimicrobial activity of honey Agar well diffusion assay}

The antibacterial efficacy of the Coorg honey samples was performed on the basis of the Clinical and Laboratory Standards Institute (CLSI) guidelines (Anthimidou and Mossialos, 2013). Briefly, overnight bacterial cultures (Streptococcus sp. (BU202031), Staphylococcus aureus (BU202016), Bacillus subtilis (BU201907) and Enterococcus sp (BU202055) procured from Department of Microbiology, Bangalore University were grown in Mueller-Hinton broth were adjusted to $0.5 \mathrm{McF}$ arland turbidity standard $\left(\sim 1.5 \times 10^{8} \mathrm{CFU} / \mathrm{ml}\right)$. Mueller-Hinton agar plates were inoculated with $10^{6} \mathrm{CFUs}$ of bacterial cultures over the entire surface of the plate. Wells of 6 $\mathrm{mm}$ in diameter were cut into the surface of the agar and $100 \mu \mathrm{l}(50 \% \mathrm{v} / \mathrm{v}$ in phosphate-buffered saline) of the tested honey samples were added separately to each well. Standard antibiotic discs of chloramphenicol $\left(\mathrm{C}^{30}\right)$, tetracycline $\left(\mathrm{TE}^{30}\right)$ and Ciprofloxacin $\left(\mathrm{CIP}^{5}\right)$ were used as positive control in the antibacterial assay. The plates were incubated at $37^{\circ} \mathrm{C}$ for $16-18 \mathrm{~h}$. The diameter of the inhibition zones, including the diameter of the well, was recorded. Each assay was carried out in triplicate.

\section{Determination of minimum inhibitory concentration (MIC) \\ The minimum inhibitory concentration (MIC) of the hon-}


ey types was determined in 96-well microtiter plates using a spectrophotometric bioassay, as previously described (Patton et al., 2006). Approximately, $5 \times 10^{4}$ CFUs of bacterial cultures in $10 \mu \mathrm{l}$ MuellerHinton broth were added to $190 \mu$ l of 2-fold diluted test honey (honey concentration ranged from 100 to $1 \% \mathrm{v} /$ v) in Mueller-Hinton broth. The optical density was determined at $630 \mathrm{~nm}$ using a micro-plate reader.MIC was defined as the lowest concentration of honey that completely inhibits bacterial growth.

\section{Statistical analysis}

The MIC results were expressed as mode (the value that appears most often) and the comparison of the antibacterial activity of the samples was evaluated by applying $t$-test. $p \leq 0.05$ values were considered to indicate statistically significant differences.

\section{RESULTS AND DISCUSSION}

The physicochemical characteristics of Apis honey samples collected from Coorg are presented in table-1. The $\mathrm{pH}$ of $A$. dorsata honey samples was highest with 5.3 and of $A$. florea was least with 3.2. The moisture content of honey samples varied from 13.6 to $17.2 \%$ and the highest was recorded in $A$. dorsata, whereas the least was found in $A$. florae and the difference in the moisture might be due to low rate of honey fermentation. The total ash content of $A$. mellifera honey was highest $(0.49 \%)$ and of $A$. cerana was least $(0.32 \%)$. The HMF (Hydroxy methyl furfurals) content of A. dorsata honey samples was highest with $9.2 \pm 0.5$ $\mathrm{mg} / \mathrm{Kg}$ and least was recorded with $6.8 \pm 0.4 \mathrm{mg} / \mathrm{Kg}$ for $A$. florae honey. The reducing sugar content of $A$. florea honey sample was highest with $87.5 \pm 3.2(\%)$ and was least recorded with $53.4 \pm 1.5(\%)$ for honey of $A$. dorsata. The sucrose content of $A$. dorsata honey was highest with $6.5 \pm 0.7(\%)$ and least with $4.8 \pm 0.4$ percent for $A$. florea and $A$. cerena honey. The peroxide content of A. florae honey was the highest with $14.9 \pm 0.1 \mu \mathrm{g} / \mathrm{g} / \mathrm{h}$ at $20^{\circ} \mathrm{C}$ and of $A$. dorsata was least with $10.2 \pm 0.5 \mu \mathrm{g} / \mathrm{g} / \mathrm{h}$ at $20^{\circ} \mathrm{C}$. The probable reasons for the variations of physicochemical characteristicsis due to the honey bee species and their floral sources.

All the honey samples showed different levels of growth inhibition on all the bacteria tested. The results of antibacterial assay revealed that $S$. aureus, Enterococcus $\mathrm{sp}$ and Streptococcus $\mathrm{sp}$ were most susceptible against the honey varieties tested (Fig.1). A. florea honey had highest antibacterial activity against $S$. aureus with a zone of inhibition of $4.5 \mathrm{~mm}$ whereas Enterococcus $\mathrm{sp}$ was the most susceptible organism (4.1 $\mathrm{mm}$ ) for $A$. dorsata followed by Streptococcus sp (3.9 $\mathrm{mm})$. A. mellifera was effective against $S$. aureus while $A$. cerena was equally effective against both $S$. aureus and Streptococcus sp. Varying antibacterial activity of honey samples might be influenced by the bee's source of nector, floral type and phytochemicals present in the honey. This findings is in accordance with previous studies reported that different honey types possess different efficacies and mechanisms against the same bacteria (Cebrero et al., 2020; Al-Masaudi, 2020, Al-Masaudi et al., 2017\&2020; Lu et al., 2014; Carnwath et al., 2014)

The results of minimum inhibitory concentration values for the honey samples against the different bacteria tested are shown in Fig.2. The highest inhibition zone was recorded against $S$. aureus $(3.9 \pm 0.7 \mathrm{~mm})$ while it was $3.1 \pm 0.1 \mathrm{~mm}$ against Enterococcus $s p$. The data was significant at $p<0.01$ for $A$. florea and $A$. cerana honey samples and $\mathrm{p}<0.05$ for $A$. mellifera and $A$. dorsata honey samples. Cebrero et al. (2020) reported that the minor constituents such as phenolic compounds, antioxidant enzymes present in the honey contribute substantially to the antibacterial activities of honey. As this study used four different honey varieties, variations in the antibacterial activity is justified based on the nature and composition of honey samples.

The use of honey for treating microbial infections is an ancient process (Molan, 1992) and one of the predominant antimicrobial agents in honey is hydrogen peroxide generated when the honey is peroxide levels were in the range of diluted (Weston, 2000). In this study the peroxide levels were found to be in the range of 10.2$14.9 \mu \mathrm{g} / \mathrm{g} / \mathrm{h}$.Both Gram-positive and Gram-negative pathogenicbacteria are susceptible to honey and the antibacterial activity is attributed to its osmolarity, $\mathrm{H}_{2} \mathrm{O}_{2}$ content, low $\mathrm{pH}$, phenolic compounds and flavonoids(Jenkins et al., 2014; Lusby et al., 2005; ManyiLoh et al., 2006). Similarly, Nayaka et al., (2020) re-

Table 1. Physicochemical characteristics of Apis honey samples from Coorg, Karnataka.

\begin{tabular}{llllllll}
\hline Honey Types & $\mathbf{p H}$ & $\begin{array}{l}\text { Moisture } \\
\text { Content (\%) }\end{array}$ & Ash (\%) & $\begin{array}{l}\text { HMF (mg/ } \\
\mathbf{k g})\end{array}$ & $\begin{array}{l}\text { Reducing } \\
\text { Sugars (\%) }\end{array}$ & $\begin{array}{l}\text { Sucrose } \\
(\%)\end{array}$ & $\begin{array}{l}\text { Peroxide } \mathbf{\mu g} / \\
\mathbf{g} / \mathbf{h} \text { at 20 }\end{array}$ \\
\hline A. florea & $3.2 \pm 0.6$ & $13.6 \pm 2.0$ & $0.41 \pm 0.2$ & $6.8 \pm 0.4$ & $87.5 \pm 3.2$ & $4.8 \pm 0.4$ & $14.9 \pm 0.1$ \\
A. mellifera & $4.7 \pm 0.1$ & $14.5 \pm 0.0$ & $0.49 \pm 0.5$ & $8.0 \pm 1.8$ & $77.4 \pm 0.2$ & $3.6 \pm 0.5$ & $11.4 \pm 0.7$ \\
A. cerana & $4.2 \pm 0.2$ & $15.8 \pm 2.1$ & $0.32 \pm 0.9$ & $8.5 \pm 0.2$ & $66.2 \pm 0.7$ & $4.8 \pm 0.7$ & $10.9 \pm 0.8$ \\
A. dorsata & $5.3 \pm 0.4$ & $17.2 \pm 0.0$ & $0.41 \pm 0.3$ & $9.2 \pm 0.5$ & $53.4 \pm 1.5$ & $6.5 \pm 0.7$ & $10.2 \pm 0.5$ \\
\hline
\end{tabular}




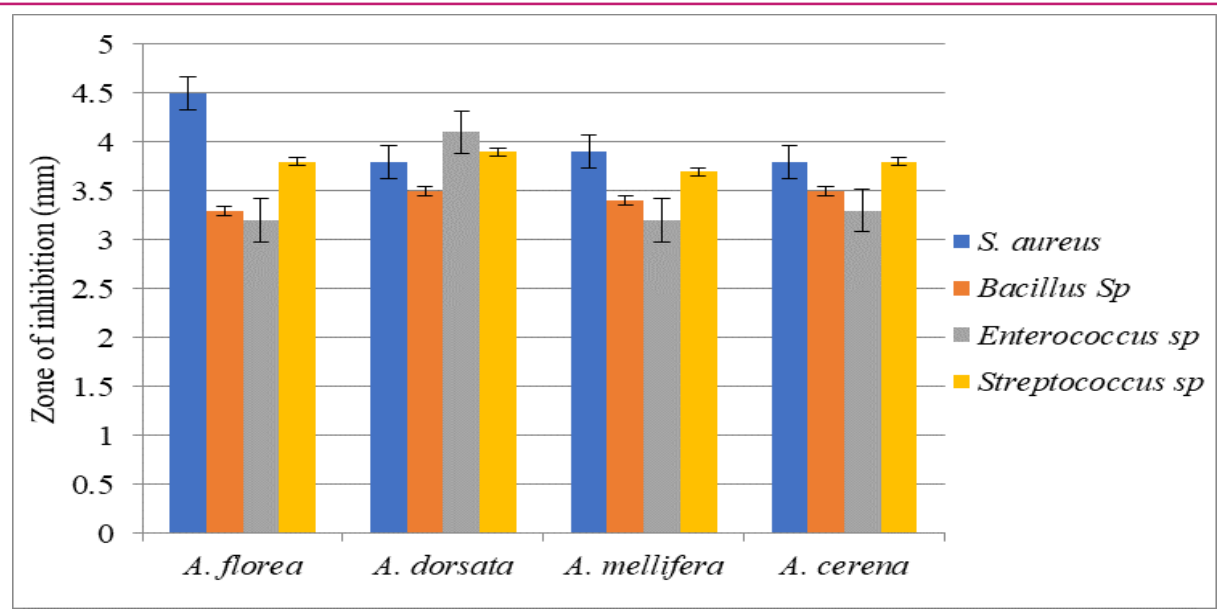

Fig. 1. Zone of inhibition of Apis honey samples from Coorg, Karnataka.

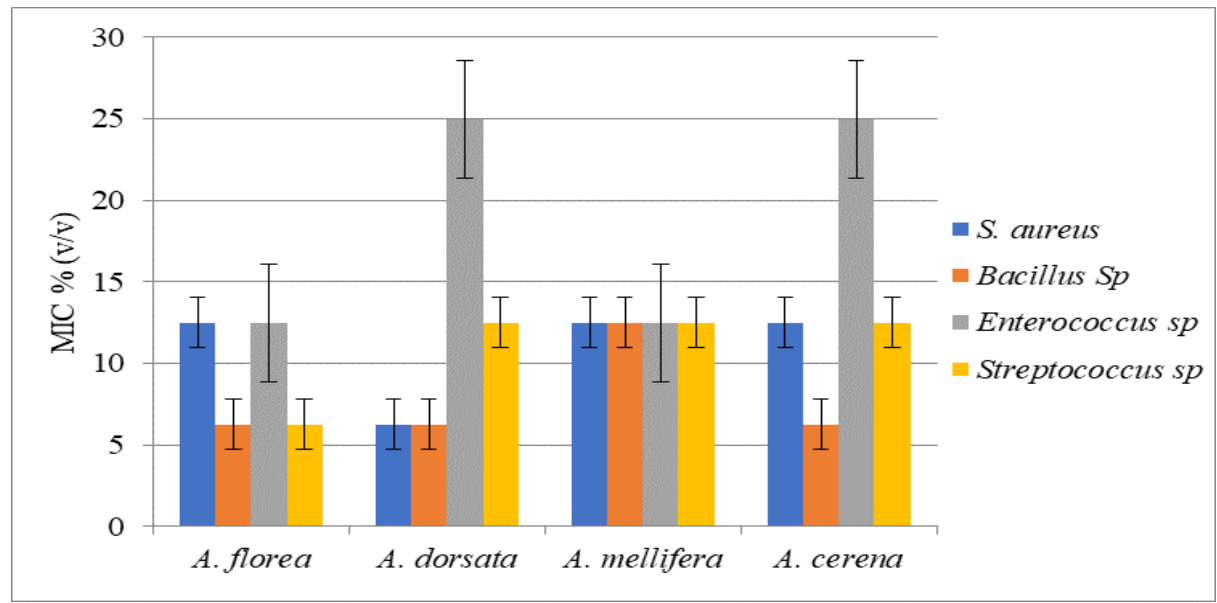

Fig. 2. MIC \% (v/V) values of Apis honey samples from Coorg, Karnataka.

ported that bioactivities of honey are influenced by geographical regions and phytochemical profiles of the honey. The other components with antimicrobial potential of honey are catalase, glucose oxidase, nonperoxide components and methylgloxal (Simon et al., 2009). It is known that acidic $\mathrm{pH}$ is inhibitory to many bacterial pathogens and the natural acidic nature of honey is good enough for its antibacterial properties (Haniyeh et al., 2010). The four honey samples derived from Coorg were with $\mathrm{pH}$ between 3.2 and 5.3 and that might have attributed to the antibacterial activity of the honey samples tested. The $\mathrm{pH}$ values were in accordance with the results of Bogdanov (1997) and Jyothi (2006). Floral sources is the another factor influences the varying antibacterial nature of the honey samples tested. It has also been reported that physical property, geographical distribution may play important role in the antimicrobial activity of honey (Nayaka et al., 2020).

The higher the concentration of honey the greater its antibacterial activity (Badawy et al., 2004) and 50\% $\mathrm{v} / \mathrm{v}$ in phosphate-buffered saline was used for antimicrobial assay in this present study. Further, honey con- centration ranged from 100 to $1 \% \mathrm{v} / \mathrm{v}$ was used in MIC assay to determine the usefulness of honey varieties in controlling bacterial growth. Earlier studies by Albaridi, (2019), Anand et al., (2019), Matzen et al. (2018) and Adeleke et al. (2006) mentioned the use of diluted honey in controlling the bacterial growth and the dilutions could be confirmed through in vivo and clinical studies.

\section{Conclusion}

Physicochemical properties of the honey play a substantial role in its antibacterial activity. Variations in the antibacterial activity could be attributed by the honey bee species, floral varieties even it is collected from the same geographical region hence identification of appropriate honey type to control the specific bacterial growth is required. Further deciphering of phytochemicals in the effective honey variety is important in order to use the honey against specific pathogens.

\section{Conflict of interest}

The authors declare that they have no conflict of interest. 
Bhushanam M. et al. / J. Appl. \& Nat. Sci. 13(2), 729 - 734 (2021)

\section{REFERENCES}

1. Adeleke, O.E., Olaitan, J.O. \& Okpekpe, E.L. (2006). Comparative antibacterial activity of honey and gentamicin against Escherichia coli and Pseudomonas aeruginosa. Ann Burns Fire Disasters. 19, 201-204

2. Albaridi, N.A. (2019). Antibacterial potency of honey. International Journal of Microbiology, 2464507. DOI: $10.1155 / 2019 / 2464507$

3. Al-Masaudi, S.B. (2020). The antibacterial activities of honey. Saudi Journal of Biological Sciences. 28, 21882196. DOI: 10.1016/j.sjbs.2020.10.017

4. Al-Masaudi, S.B., Al-Nahari, A.A.M., Abd El-Ghany, E.S.M., Barbour, E., Al Muhayawi, S.M., Al-Jaouni, S., Azhar, E., Qari, M., Qari, Y.A. \& Harakeh, S., (2017). Antimicrobial effect of different types of honey on Staphylococcus aureus. Saudi Journal of Biological Sciences, 24 1255-1261. DOI: 10.1016/j.sjbs.2016.08.007

5. Al-Masaudi, S.B., Hussain, M.B., Al-Maaqar, S.M., Al Jaouni, S. \& Harakeh, S. (2020). In vitro antibacterial activity of honey against multidrug-resistant Shigella sonnei. Complementary Therapies in Clinical Practice, 41, 101257. DOI: 10.1016/j.ctcp.2020.101257

6. Anand, S., Deighton, M., Livanos, G., Morrison, P.D., Pang, E.C.K. \& Mantri, N. (2019). Antimicrobial activity of Agastache honey and characterization of its bioactive compounds in comparison with important commercial honeys. Frontiers in Microbiology, 10. DOI: 10.3389/ fmicb.2019.00263

7. Anthimidou, E. \& Mossialos D. (2013). Antibacterial activity of Greek and Cypriot honeys against Staphylococcus aureus and Pseudomonas aeruginosa in comparison to manuka honey. Journal of Medicinal Food. 16, 42 47.DOI: 10.1089/jmf.2012.0042

8. Badawy, O.F., Shafii, S.S., Tharwat, E.E. \& Kamal, A.M. (2012). Antibacterial activity of bee honey and its therapeutic usefulness against Escherichia coli 0157:H7 and Salmonella typhimurium infection. Rev Sci Tech. 23,10111022.DOI: $10.20506 /$ rst.23.3.1543

9. Blair, S.E., Cokcetin, N.N., Harry, E.J. \& Carter, D.A. (2009). The unusual antibacterial activity of medical-grade Leptospermum honey: Antibacterial spectrum, resistance and transcriptome analysis. Eur J Clin Microbiol Infect Dis. 28, 1199-1208. DOI: 10.1007/s10096-009-0763-z

10. Bogdanov, S. (1997). Nature and origin of the antibacterial substances in Honey, LWT- Food Science and Technology I, 30, 748-753. DOI: 10.1006/fstl.1997.0259

11. Bogdanov, S., Ruoff, K.\& Oddo, L.P. (2004). Physicochemical methods for the characterization of unifloral honeys: a review, Apidologie, 35, S4-S17.DOI:10.1051/ apido:2004047

12. Bogdanov, S., Lullman, C. \& Martin, P. (1999). Honey Quality and international regulatory standards. Review of the work of the International Honey Commission, Mitt. Gebiete Lebensm. Hyg. 90,108-125. DOI: 10.1080/0005772X.1999.11099428

13. Carnwath, R., Graham, E., Reynolds, K. \& Pollock, P. (2014). The antimicrobial activity of honey against common equine wound bacterial isolates. Vet. J., 199, 110114

14. Cebrero, G., Sanhueza, O., Pezoa, M., Baez, M.E., Martínez, J., Baez, M. \& Fuentes, E. (2020). Relationship among the minor constituents, antibacterial activity and geographical origin of honey: A multifactor perspective. Food Chemistry, 126296. DOI: 10.1016/ j.foodchem.2020.126296

15. Cooper, R.A., Molan, P.C. \& Harding, K.G. (2002). The sensitivity to honey of Gram-positive cocci clinical significance isolated from wounds. J. Appl. Microbiol. 93, 857863. DOI: 10.1046/j.1365-2672.2002.01761.x

16. Haniyeh, K., Seyyed, M.S. \& Hussein, M. (2010). Preliminary study on the antibacterial activity of some medicinal plants of Khuzestan (Iran). Asian Pac J Trop Med. 3, 180184.DOI: 10.1016/S1995-7645(10)60004-1

17. Hussain M.B. (2018). Role of honey in topical and systemic bacterial infections. Journal of Alternative and Complementary Medicine (New York, N.Y.), 24, 15-24.DOI: 10.1089/acm.2017.0017

18. Hussain, M.B., Hannan, A., Akhtar, N., Fayyaz, G.Q., Imran, M., Saleem, S. \& Quereshi, I.A. (2015). Evaluation of the antibacterial activity of selected Pakistani honeys against multidrug resistant Salmonella typhi.BMC Complement Altern Med 15,32. DOI: 10.1186/s12906-015-0549-z

19. Jenkins, R., Burton, N. \& Cooper, R. (2014). Proteomic and genomic analysis of methicillin-resistant Staphylococcus aureus (MRSA) exposed to manuka honey in vitro demonstrated down-regulation of virulence markers. Journal of Antimicrobial Chemotherapy. 69, 603-615.DOI: 10.1093/jac/dkt430

20. Jyothi, J.V.A. (2006). Physicochemical analysis of honey of different honeybees, Apis cerana, Apis dorsata, Apis mellifera and Apis florea. J. Ent. Res.30, 43-45.

21. Kerkvliet, J.D. (1996). Screening method for the determination of peroxide accumulation in honey and relation with HMF content. Journal of Apicultural Research. 35, 110117. DOI: $10.1080 / 00218839.1996 .11100920$

22. Kwakman, P.H., te Velde, A.A., de Boer, L., Speijer, D., Vandenbroucke-Grauls, C.M. \& Zaat, S.A. (2010). How honey kills bacteria. FASEB Journal: Official publication of the Federation of American Societies for Experimental Biology, 24,2576-2582. DOI: 10.1096/fj.09-150789

23. Lu, J., Turnbull, L., Burke, C.M., Liu, M. Carter, D.A., Schlothauer, R.C., Whitchurch, C.B. \& harry, E.J. (2014). Manuka-type honeys can eradicate biofilms produced by Staphylococcus aureus strains with different biofilmforming abilities. PeerJ, 2, e326. DOI: 10.7717/peerj.326

24. Lusby, P.E., Coombes, A.L. \& Wilkinson, J.M. (2005). Bactericidal activity of different honeys against pathogenic bacteria. Archives of Medical Research, 36, 464-467.DOI: 10.1016/j.arcmed.2005.03.038

25. Manyi-Loh, C.E., Clarke, A.M., Munzhelele, T., Green, E., Mkwetshana, N.F. \& Ndip, R.N. (2010). Selected South African honeys and their extracts possess in vitro antiHelicobacter pylori activity. Archives of Medical Research, 41, 324-331.DOI: 10.1016/j.arcmed.2010.08.002

26. Matzen, R.D., Leth-Espensen, J.Z., Jansson, T., Nielsen, D.S., Lund, M.N. \& Matzen, S. (2018). The antibacterial effect in vitro of honey derived from various Danish flora. Dermatology Research and Practice, 2018, Article ID 7021713, 10 pages, DOI: 10.1155/2018/7021713

27. Mohan, A., Quek, S.Y., Gutierrez-Maddox, N., Gao, Y. \&Shu, Q. (2017). Effect of honey in improving the gut microbial balance, Food Qual. Saf. 1, 107-115. DOI: 10.1007/s00253-016-7870-4 
28. Molan, P.C. (1992). The antibacterial nature of honey. The nature of the antibacterial activity. Bee World. 73,5-28.

29. Nayaka, N.M.D.M.W., Fidrianny, I., Sukrasno, Hartati, R., \& Singgih, M. (2020). Antioxidant and antibacterial activities of multiflora honey extracts from Indonesian Apis cerana bee. Journal of Taibah University Medical Sciences. 15, 211-217. DOI; 10.1016/j.jtumed.2020.04.005

30. Patton, T., Barrett, J., Brennan, J.\& Moran, N. (2006). Use of a spectrophotometric bioassay for determination of microbial sensitivity to manuka honey. J Microbiol Methods. 64, 84-95.DOI: 10.1016/j.mimet.2005.04.007

31. Qui, P.Y., Ding, H.B. Tang, Y.K. \& Xu, R.J. (1999). Determination of Chemical Composition of Commercial honey by near infrared spectroscopy. J. Agric. Food Chem.47, 2760- 2765. DOI: 10.1021/jf9811368

32. Sanz, M.L., Polemis, N., Morales, V., Corzo, N., Drakoularakou, A., Gibson, G.R. \& Rastall, R.A. (2005). In vitro investigation into the potential prebiotic activity of honey oligosaccharides.J.Agric. Food Chem. 53,29142921. DOI: 10.1021/jf0500684

33. Simon, A., Traynor, K., Santos, K., Blaser, G., Bode, U.\& Molan, P. (2009). Medical honey for wound care--still the 'latest resort'? Evid Based Complement Alternat Med. 6, 165-173. DOI: 10.1093/ecam/nem175.

34. Weston, R.J. (2000). The contribution of catalase and other natural products to the antibacterial activity of honey: a review. Food Chemistry. 71, 235-239. DOI: 10.1016/ S0308-8146(00)00162-X

35. White, J.W. (1977). Specific determination of sucrose in honey. Journal of the Association of Official Analytical Chemists, 60, 669-672.DOI: 10.1093/jaoac/60.3.669

36. White, J.W. (1979). Spectrophotometric method for hydroxymethyl furfural in honey. Journal of the Association of Official Analytical Chemists, 62, 509-514.DOI: 10.1093/ jaoac/62.3.509 